he use of 1080 poison.

Along its course from the Rockies - Hudson Bay, the Saskatchewan River probably cuts through no igher land than here in the Coteau iills at an altitude of over 2,500 feet. Here the distance from top land level o river high water mark may be ver 500 feet. For a stretch of almost 0 miles, therefore, the river banks

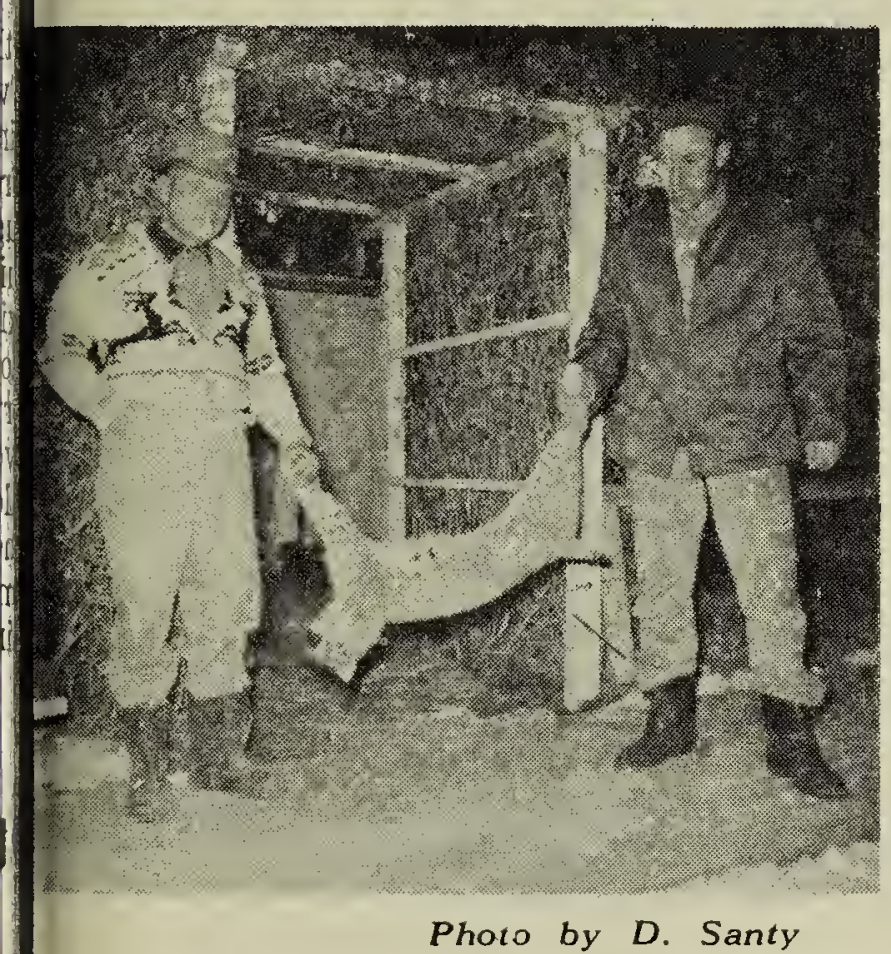

Bob cat taking a cat nap.

present about three miles of rough errain which is the haunt of deer ind other forms of wildlife. Bob cats have always been with us in these iver breaks, but they are infrequenty seen. Since bob cats are known or their wariness, it was a surprise 0 deer hunters Abe Penner and rank Odermatt to come across one his fall fast asleep and to view it or a time in that state before disatching it with a rifle shot. The cat veighed 20 lbs. Two weeks later ancher Pete Perrin saw another cat when he crossed on the river ice near he Herpert ferry.

Looking back over the past 45 rears we are reminded that the odd brush wolf was trapped here, and down through the years the occasicnal pair has been seen in the district.

Those who have read Palliser's ieport may remember that when his expedition forded the river at the Elbow several bear were seen and ore shot to replenish their meat supply. Last summer it was said that signs $\mathrm{C} f$ a bear were seen around Bcunty or Anerley but no confirmation of the actual presence of such on animal has come to us.

\section{Further Records of Raccoons in Saskatchewan}

In addition to the report of raccoons at Beechy in the foregoing article, there have been four reports of raccoons submitted to the editor since the printing of our last Blue Jay.

Lad Martinovsky of Gerald found one killed on the highway about one mile west of town in the Cut Arm valley in September, 1957. This is apparently the first one killed in his district. J. Stewart Houston of Tyvan also tells of a raccoon being taken this fall by a trapper near Redvers. His sister, Mrs. Marion Nixon, has heard reports of raccoons near Wauchope

K. E. Baines of Tisdale writes that a large male raccoon appeared two years ago on the Frank Pearse farm at Leacross. This ralccoon was raiding the hen house so it was trapped and transferred to a cage. When spring came it was released and it wasn't seen again.

John Hunter, taxidermist, Saskatoon writes that he has a raccocn in his wildlife exhibit, which was taken near Pleasantdale on January 18, 1954. This raccoon had been in a fight with a dog and had had to be destroyed.

\title{
The Thrills and Disappointments of the 1957 Big Game Hunt
}

By E. M. Morgan, Viewfield, Sask.

I own a summer resort on Candle Lake 65 miles northeast of Prince Albert and I am naturally interested n big game hunting. On the mornng when the early moose season cpened last fall, Joe and Frank Hayes and myself took Joe's jeep and drove some 40 miles north east of Candle Lake into the heart of the moose pastures. We spent the night in a 
trapper's cabin Joe had at Leonard Lake and rose early the next morning, to look out on a real old-fashioned snow storm raging over the lake. Soon, however, the sun was shining and by noon all the snow was gone. We drove to Skunk Lake where we had seen signs of moose the day before and left the jeep there to scout the area on foot. Some three or four hours later Frank and I arrived back at Skunk Lake without having seen any sign of either moose or our partner Joe. While we were trying to decide what to do about Joe we heard a shot up the lake, and Frank remarked: "Well, I guess that was Jce. He must have got his moose. I'll run up on that hill and maybe if there is more than one animal, one of us might get a shot at it."

Frank had only run about three hundred yards when I saw a threeyear-old bull moose coming toward me, picking his way through the timber burn. I stood very still and waited till he was about 50 yards from me and tried for a brain shot, but just as I pulled the trigger of my 30/06 the moose stopped to look around and my shot took him just below the eye. I at once put another shot through his lungs and thiat was when he spotted me. Then I got the biggest thrill of my life because I had a mad wounded moose to contend with and no trees near to climb. The moose was making for me and the only thing I could do was wait and take my chance cn a brain shot. This I did when the moose was within 20 feet of me. My luck held, for when I fired he dropped right then-stone dead.

We three dicessed out the moose, quartered it and loaded it into the jeep for the long trek home over rough roads, mud holes and sand pits. According to the hunting law, my having shot a moose put me out of the hunting until the late moose, deer and elk season, and the worst of it was that I could no longer carry a rifle even to hunt bears! This was quite a disapointment for while I was driving through the various trails in the bush with a friend of mine from Regina showing him the country, we came upon a large black bear and two cubs right on the road and me with no rifle. Just a few years before this the wife and I had shot five bears in one afternoc so you can see why it was quite disappointment not having a gun this time. Well, that made thr bears that got away!

When the deer and elk seas cpened later I had both licences, went cut one day into the meadc west of my resort to try and $g$ a deer. I was hidden in the gra calling a deer out of the willows the edge of the meadow, when sor instinct told me to lcok back of $r$ and I turned around to see one the largest bull moose I had ev seen walking right towards me. $\mathrm{Tr}$ moose had a spread of horns that man could reach from point to poi and he looked as if he weighed ton. I ireally think this was $t$ largest moose in the north countr and two other men who had se it said the same thing about it. was at a loss as to what to do I had no legal right to shoot th moose, having shot a moose earli in the season. I decided the only thi I could do was to try and fright it and if it charged me to shoot in self-defence.

The public road was only abo 100 yards away and just at that tin a small red truck stopped and $t$ door opened slowly and out poked rifle barrel. The hunters in the tru were going to shoot from the truo which is strictly against the law. took me only a' second to decide wh to do then. I jumped cut of $t$ grass and the moose, which was on about twenty yards away by the took fright and disappeared into tl willows in a couple of jumps. T men in the truck saw me jump o of the grass and did not shoot. walked over to them and told the that they were liable on two charg - one for having a loaded gun in uruck, and the other for shootir from a road within thirty yards a summer resort. They said the had nct shot, but their gun w loaded and they would have taks the chance if I had not shown 1 when I did. Some sportsmen, tho guys!

A couple of days later I dropp a deer and while dressing it $o$ another deer walked up with twenty yard's of me and watch me dress it out! Of course, I cou not shoot it as I only had the or deer licence. Then the next wer 
while I was on stiand near a game reserve I had two deer walk within three feet of me and one of them I could have poked in the ribs with the gun barrel. And I had a cow moose walk to within twenty yards of me. look me over and then walk away into the bush! It is a caution how close animals will come to you if you stand very still near a tree or bush and remain absolutely motionless while they are in sight.

The list and greatest disappointment occurred while I was trying to get my elk. A hunter came into the district in a large truck with a pony in the back and a toboggan to which he intended to hitch the pony. $\mathrm{He}$ put a red blanket on the pony and also a set of bells, and he and his pard drove all through the timber for miles in that district riding the toboggan looking for elk. He would follow a bunch of elk tracks and chase the elk right out of the district, doing this day after day till the end of the season. The only thing he saw was a lot of elk tracks, and the elk sure made a lot of them for him! He never got within miles of the elk with that silly outfit he had; all he did was spoil the hunting for about a dozen other hunters. You can see the reason why this was one season I myself did not get my elk.

EDITOR'S NOTE: In response to frequent appeals in the past for contributions from hunters and members of the province's fish and game leagues, we have this delightful account of Mr. Morgan's hunting experiences. We teel that the hunter who takes a legitimate harvest cf game within the legal limits of an intelligently planned game management programme plays an important role in the utilization of our natural resources.

\section{New Elk Display at Museum}

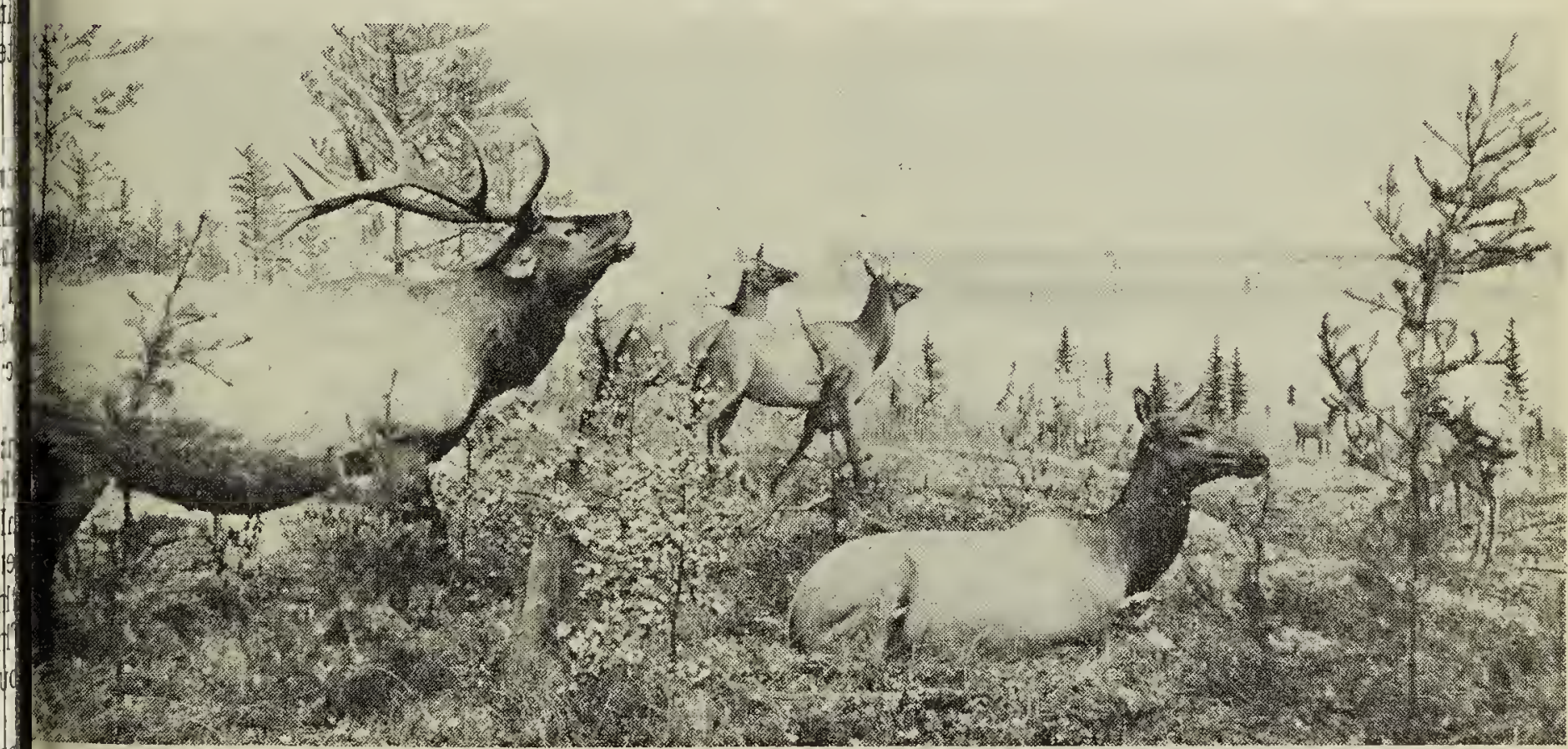

Sask. Govt. Photo

The above photograph shows the recently completed elk display at the Saskatchewan Museum of Natural History. The elk display was officially opened by Fred Bard, Director of the Museum, at an interesting ceremony held January 20 in conjunction with the regular monthly meeting of the Regina Natural History Society.

The habitat displays in the new museum have been planned to represent the variety of environments and wildlife characteristic of the province of Saskatchewan, Mr. Bard said in opening the new display. The display of North American elk or wapiti in a natural setting-along the north bank of the Saskatchewan River east of the Fort à la Corne Provincial Forest-completes the series of 24 habitat groups.

The elk display shows a bull elk and his harem. The season is midSeptember and the elk is at his prime; his antlers are fully grown and his bugling challenge rings across the river. A commanding ridge, such as the one seen here, serves as an excellent vantage point from which the 